\title{
Dampak Implementasi Penggunaan Teknologi Manufaktur Tingkat Lanjut-Advanced Manufacturing Technology pada Kinerja UKM di Indonesia
}

\author{
Jani Rahardjo ${ }^{1}$
}

\begin{abstract}
In Indonesia, 99.8\% of the businesses are SMEs. However, those SMEs only contribute to the $56.7 \%$ of the Indonesia GDP. This happened, mainly due to the limitations of SMEs which use traditional technologies in the production process. Therefore, in 2014, the Indonesian government through the Ministry of Cooperation and Small Medium Entreprises launced a new strategic plan to empowering the SMEs by applying the Advanced Manufacting Technology (AMT). It is believed that applying the AMT in the SMEs can increase productivities, expand the market share and raised national economic growth. This study, identified the used of AMT in the Indonesia SMEs, especially in foods, beverages, herbal and handicraft sectors. Additionally, it is also measured the impact of the used of AMT in the SMEs' performaces. In this study, it is found that $76.6 \%$ of the total sampel (253 SMEs) declared that they use the AMT. This indicates that the Indonesia SMEs have a clear operation mission, process production, high quality products and meet the customer's satisfaction. It is also found that the percentage of the hard technology is higher than the soft technology. This showed that there is a large effort to increase the productivity in the process production. Finally, we found that the impact of the AMT used to the SMEs' performance in the market share, profitability and organization performance is increased significantly.
\end{abstract}

Keywords: AMT, SME, SME's performance.

\section{Pendahuluan}

Salah satu efek dari globalisasi pada negara sedang berkembang dan negara berkembang adalah kemudahan suatu produk masuk ke dalam pasar global yang mengakibatkan terjadinya peningkatan pertumbuhan ekonomi nasional (Raymond dan Croteau [1]). Peluang pasar semakin terbuka seiring dengan tingginya tututan pelanggan akan suatu produk yang berkualitas, rendah biaya, kecepatan pengiriman dan fleksibilitas variasi produk (Monge et al. [2]).

Implementasi penggunaan Teknologi Manufaktur tingkat lanjut (Advanced Manufacturing Technology (AMT) yang diterapkan pada suatu perusahaan mempunyai peranan penting dalam pemenuhan keinginan pelanggan dan menjadi keunggulan bersaing bagi perusahaan untuk mendapatkan peluang pasar di era Globalisasi. Saleh dan Ndubisi [3] membuktikan bahwa perusahaan besar atau perusahaan multinasional telah berhasil mengadopsi AMT sehingga membuat proses produksi semakin produktif dan efisien. Monge et al. [2] menyatakan bahwa kinerja AMT pada proses produksi dan organisasi dipengaruhi beberapa faktor diantaranya

\footnotetext{
1 Fakultas Teknologi Industri, Program Studi Teknik Industri, Universitas Kristen Petra. Jl. Siwalankerto 121-131, Surabaya 60238. Indonesia, Email: jani@petra.ac.id

* Penulis korespondensi
}

besarnya investasi, perencanaan, proses implementasi serta evaluasi implementasi. Implementasi AMT membutuhkan perencanaan yang baik pada tingkatan operasi maupun manajemen perusahaan untuk menjamin tercapainya tujuan implementasi AMT. Perusahaan kecil dan menengah (UKM) yang mempunyai karakteristik rendah investasi, perencanaan produksi yang tidak teratur, sistem produksi dalam jumlah kecil, kepemilikan sendiri berbeda dengan perusahaan besar dimana semua faktor penunjang implementasi AMT dapat terpenuhi. Hal ini menimbulkan beberapa pertanyaan, seperti: Apakah UKM dapat sukses menerapkan AMT? Apakah dengan penerapan AMT berdampak pada kinerja UKM? Pada kenyataannya, dalam dekade krisis ekonomi pertengahan tahun 1998 performa industri besar di dunia turun tajam tetapi UKM mampu bertahan dan memegang peranan penting dalam pertumbuhan ekonomi di negara sedang berkembang dan negara berkembang. Peranan UKM di Indonesia dalam peningkatan pertumbuhan Ekonomi Nasional sangat tinggi terutama dalam kontribusi terhadap Produk Domestik Bruto (PDB). 99,8\% usaha di Indonesia adalah UKM dimana UKM telah memberikan sumbangan sebesar 56,7\% kepada PDB (Tambunan [4]). Kecilnya kontribusi UKM terhadap PDB bila dibandingkan dengan besarnya proporsi UKM yang ada di Indonesia dapat terjadi karena kebanyakan UKM di Indonesia masih menggunakan alat produksi yang tradisional. Hal ini mendorong pemerintah melalui 
Kementerian Koperasi dan Usaha Kecil Menengah (UKM) untuk mencanangkan Rencana Strategis 2014 yaitu pemberdayaan UKM dengan penggunaan Teknologi Manufacktur Tingkat Lanjut (AMT).

\section{Metode Penelitian}

\section{Advanced Manufacturing Technology (AMT)}

Konsep skema AMT telah banyak diuraikan oleh beberapa peneliti. Raymond [5] mendefinisikan AMT sebagai sistem produksi otomatis yang merupakan integrasi dari tenaga kerja, mesin, alat alat untuk perencanaan, kontol dan proses produksi termasuk pembelian bahan baku, suku cadang, komponen produksi, pengiriman, dan jasa produk akhir. AMT terdiri dari teknik manufaktur baru, kombinasi antara mesin, informasi teknologi, mikroelektronic dan manajemen organisasi baru di dalam proses manufaktur (Deruntz et al. [6]). Definisi AMT menurut Jonsson [7] adalah variasi teknologi yang berbasiskan penggunaan komputer untuk mengontrol atau memonitor proses manufaktur. Sejalan dengan peneliti sebelumnya, Monge et al. [2] mendefinisikan AMT adalah sebuah kumpulan teknologi berbasiskan komputer yang digunakan pada semua proses manufaktur dimulai dari input, proses dan output. Lebih khusus, AMT dapat dideskripsikan sebagai kelompok teknologi yang berbasiskan komputer termasuk: Computer aided design (CAD), Computer aided manufacturing (CAM), Materials requirements planning (MRP), Manufacturing resources planning (MRPII), Enterprise resources planning (ERP), Electronic data interchange (EDI), Optimized production technology (OPT), Quality control software (QCS), Statistical Process Control (SPC), Expert systems, Manufacturing automation protocol (MAP), Database management systems, Mainframe, Minis, LAN/WAN, Online process instrumentation, Shop floor data capture, Graphics hardware, Automatic assembly, Flexible assembly systems, Manufacturing cells, Automated warehousing/order picking, Automatic testing equipment, Equipment controlled by programmable automation, Robot-based operations, Numerical control machines (NC), Automated handling of materials, Flexible manufacturing systems (FMS) Implementations, Computer-based inventory management, Computerbased bar-coding, Computer-based maintenance management, Computer-based production scheduling, ISO, Total Quality Management (TQM), Just in Time (JIT) (Narain et al. [8], Raymond [5] dan Salaheldin [9]). Definisi lain dari AMT, dapat diklasifikasikan menjadi Direct AMT, Indirect AMT dan Administrasi AMT (Beaumont et al. [10]).

Monge et al. [2] mengelompokan AMT menjadi Teknologi Manufaktur langsung, (DMT), Adminis- trative-information exchange - strategic technologies (AIET), Integrative manufacturing technologies (IMT), Administrative-planning technologies (APT).

Sun [11], mengkategorikan AMT menjadi empat kategori berdasarkan area implementasi: Planning and Controlling, Information resource management, Product design and development, Factory automation. Sun et al. [12] mengembangkan klasifikasi AMT sebagai berikut:

1. Planning and controlling : ERP

2. Information resource management: Technology databases/product data management (PDM),

3. Product design and development, LAN-WAN/ Intranet/shared database/internet, CAD, CAE.

4. Factory automation: Integrated design processsing systems (CAD, CAE, CAM, CAPP), Numerical control machines, CNC, DNC, Computer aided inspection, FMS, FMC, automated tool change parts loading/unloading robots, automated storage-retrieval system (AR/RS) and Automated guided vehicles (AGVs).

Menurut Small [13], Vidyarthi dan Laskhari [14], taksonomi AMT adalah Design and Engineering Technologies (D'PET), Fabricating/machining and Assembly (FMA), Automated Material Handling Technologies (AMHT), Automated Inspection and Testing Systems (AITS), Information Technologies (IT). Jonsson [7], mengklasifikasikan AMT menjadi lima area: Design Technology (AMTDES), Manufacturing Technology (AMTMFG), Administrative Technology (AMTADM), Computer-based transaction of data between sub-units (HINT1) dan computer-based transaction of data between processes (HINT2). Small et al. [15] mengkategorikan AMT menjadi 4 kelompok berdasarkan Fakt6or Analysis seperti Design Technology, Manufacturing Technology, Administrative Technology and Resource Planning Technology. Berpikir dari perspektif yang berbeda, peneliti mengkategorikan penerapan AMT berdasarkan teknologi berperangkat lunak dan keras yang di implementasikan pada bahwa suatu proses produksi yang dimulai dari masukan, transformasi, output dan lingkungan.

\section{Usaha Kecil dan Menengah (UKM)}

Saat ini, UKM sulit didefinisikan secara umum karena cukup beragamnya klasifikasi UKM di tiap negara (Hashim [16]). Beberapa definisi UKM ditentukan oleh sejumlah faktor dan kriteria seperti lokasi, ukuran, usia perusahaan, struktur organisasi, jumlah karyawan, volume penjualan, nilai aset, kepemilikan, pengembangan teknologi dan inovasi (Rahman [17]). Meskipun definisi dan deskripsi UKM bervariasi, namun dalam prakteknya sebagi- 
an besar peneliti menggunakan kedua metode kuantitatif dan kualitatif untuk mendefinisikan UKM. Dalam hal kriteria kuantitatif, jumlah karyawan dan omset penjualan tahunan yang paling sering digunakan sebagai tolok ukur untuk menentukan ukuran UKM di beberapa negara sedang berkembang. Selain itu UKM dapat diklasfikasikan menurut nilai aktiva bersih, penjualan dan tingkat investasi.

Di Indonesia, ada beberapa definisi dari UKM, tergantung pada lembaga mana yang telah merilis definisi UKM. Kementerian Negara Koperasi dan UKM mendefinisikan UKM pada tahun 1995 sebagai berikut: Usaha kecil sebagai unit usaha dengan total aset awal hingga Rp 200 juta, tidak termasuk tanah dan bangunan, atau dengan nilai tahunan penjualan maksimal 1 miliar rupiah, perusahaan menengah sebagai unit usaha dengan nilai penjualan tahunan lebih dari Rp 1 miliar tapi kurang dari Rp 50 miliar. Selain itu Badan Pusat Statistik secara teratur melakukan survei UKM, menggunakan jumlah pekerja sebagai dasar untuk menentukan ukuran perusahaan. Usaha yang mempunyai karyawan antara $1-4$ orang termasuk usaha mikro. Usaha kecil didefinisikan suatu usaha yang mempunyai karyawan antar 5- 19 orang. Usaha menengah adalah usaha dengan mempekerjakan tenaga kerja antar 20 - 99 orang. Perusahaan besar adalah unit usaha dengan jumlah tenaga kerja tetap di atas 100 orang.

\section{Data dan Metodologi}

Dua ratus lima puluh tiga sampel telah di sebarkan secara random pada peserta pameran yang diselanggarakan di kota-kota besar Jakarta, Surabaya, Bandung dan Semarang. Sampel diambil dari UKM indutsri makanan, minuman, industri herbal dan handicraft. Metoda pengumpulan data yang digunakan adalah dengan menyebar kuesioner pada responden. Metoda analisa yang digunakan adalah metoda deskripsi, pengujian Kai-Kuadrat dan pengujian non parametrik Wilcoxon Sign.

\section{Hasil dan Pembahasan}

\section{Profil Responden}

Sampel sebesar 253 responden terdiri dari beberapa industri: 45,1\% responden dari industri makanan dan minuman, 15,4\% dari industri herbal dan dari industri handicraft sebesar 37,2\%. Rata-rata lamanya industri UKM beroperasi adalah 10,1 tahun dengan jangkauan keragaman dimulai dari 6 bulan hingga puluhan tahun. Pembagian responden berdasarkan klasifikasi UKM adalah 54,5\% merupakan industri mikro, 20,2\% industri kecil dan $20,6 \%$ industri menengah dan sisanya adalah industri besar. Rata-rata jumlah tenaga kerja pada UKM adalah 43 orang dan rasio tenga kerja terampil dengan jumlah tenaga kerja adalah 15,3\%. Jenis kepemilikan UKM adalah bisnis keluarga sebesar $62,1 \%$ dan 24,1\% merupakan bisnis anak perusahaan (share holding) dan sisanya adalah bisnis patungan (joint-venture).

Penerapan AMT yang dipetakan dalam proses produksi dimulai dari proses masukan, transformasi, luaran dan lingkungan serta diklasifikasikan sebagai teknologi berperangkat lunak (soft technology) dan teknologi berperangkat keras (hard technology). MIS, Automated Drafting Technologies, CAD, CAE, Automated Statistical Process Control, Quality Function Deployment, CRM, dan Forecasting dapat diklasifikasikan sebagai teknologi berperangkat lunak pada proses masukan. Teknologi berperangkat keras pada proses masukkan terdiri dari Peralatan komputer, Local Area Network (LAN), Wireless Area Network (WAN), Automation loading and unloading.

\section{Penerapan AMT}

Hasil survey dari 253 UKM yang implementasi penggunaan AMT sebesar 38,7\%. Sisanya sebesar 61,3\% UKM tidak menerapkan AMT. Namun dari hasil survey diketahui bahwa 61,3\% UKM yang tidak menggunakan AMT terdapat alasan UKM yang secara operasional tidak dapat menerapkan AMT dikarenakan AMT tidak relevan untuk diterapkan di UKM. Table 1 menunjukan deskripsi persentase alasan mengapa UKM tidak menggunakan AMT. Tabel 1 menjelaskan bahwa terdapat $80,6 \%$ atau 125 UKM tidak cocok atau tidak relevan menggunakan AMT sehingga didapatkan persentase UKM yang menerapkan AMT sebesar 76,6\%.

Gambar 1 menunjukkan terdapat empat teknologi berperangkat keras: Peralatan komputer, LAN, WAN dan automation loading and unloading yang penggunaannya di atas $50 \%$.

Dari delapan teknologi berperangkat lunak pada proses masukan terdapat empat teknologi yang penggunaannya di atas 50\%. Hal ini dapat diartikan bahwa terdapat 50\% teknologi berperangkat lunak yang penggunaannya cukup tinggi dalam proses masukan. Pada proses masukan penggunaan teknologi berperangkat keras lebih tinggi dibandingkan dengan penggunaan teknologi berperangkat lunak. 
Tabel 1. Prosentase alasan UKM tidak menggunakan AMT.

\begin{tabular}{ll}
\hline \multicolumn{1}{c}{ Alasan } & $\%$ \\
\hline Kendala keuangan & 96,1 \\
Kesulitan dalam analisa data, pengukuran dan & 94,2 \\
dokumentasi. & 91,7 \\
Investasi tinggi & 89,0 \\
Tidak jelas keuntungan dari penggunaan AMT & 87,7 \\
Perangkat komputer yang tidak memadai. & 85,8 \\
Terdapat kesenjangan pengetahuan teknikal & 80,6 \\
AMT tidak cocok diterapkan & 80,0 \\
Terdapat kesenjangan keterlibatan tenaga kerja. & \\
Terdapat kesenjangan keterlibatan pimpinan & 77,4 \\
puncak. & 66,4 \\
Pasar yang kecil &
\end{tabular}

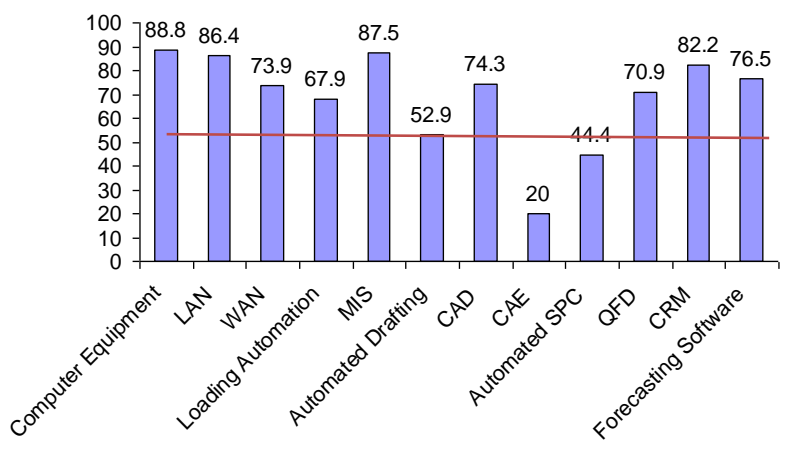

Gambar 1. Penerapan AMT pada proses masukan

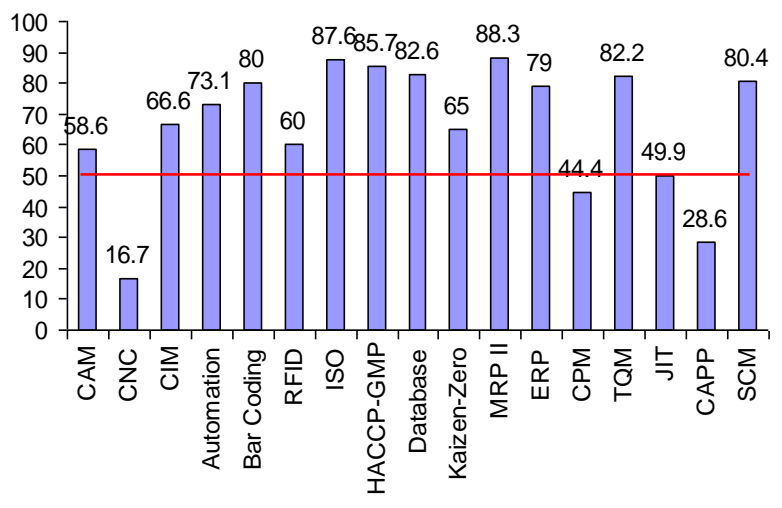

Gambar 2. Penerapan AMT pada proses transformasi

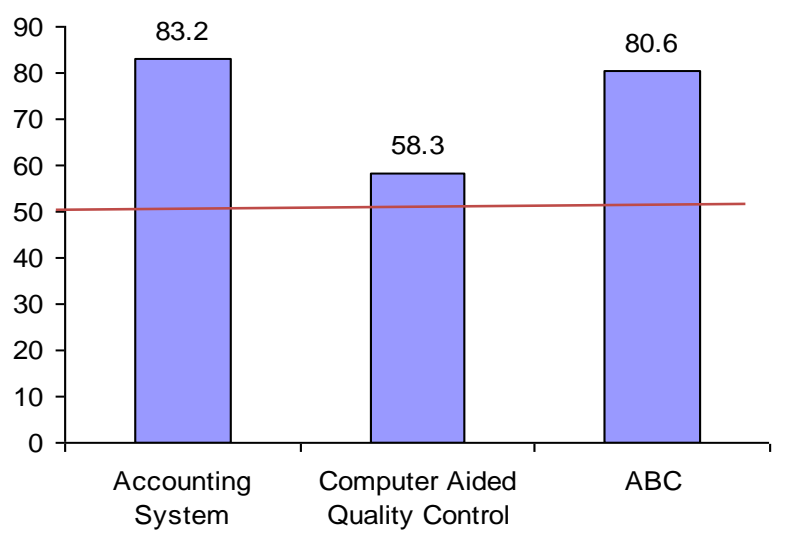

Gambar 3. Penerapan AMT pada proses luaran (output)

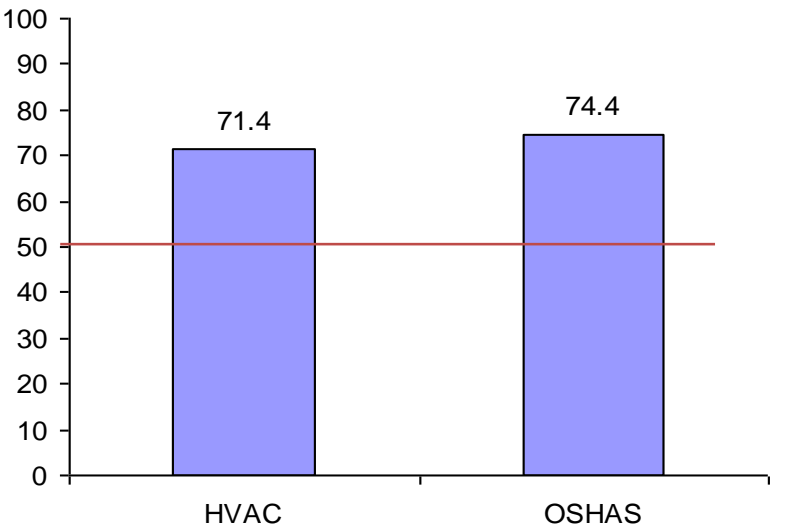

Gambar 4. Penerapan AMT pada lingkungan

Klasifikasi dari teknologi berperangkat lunak pada proses tranformasi dapat diuraikan sebagai berikut: ISO, HACCP-GMP, Database Management System, Kaizen, Zero, Defect Program, MRPII, ERP, CPM TQM, JIT, CAPP, dan SCM. Teknologi berperangkat keras adalah CAM, CNC, CIM, Automation of Testing equipment, Bar Coding, RFID.

Gambar 2. mendeskripsikan tentang prosentase penggunaan AMT di proses transformasi. Di dalam proses transformasi diketahui bahwa penggunaan tertinggi dari teknologi berperangkat keras adalah penggunaan bar coding (80\%). Penggunaan tertinggi teknologi berperangkat lunak adalah MRP II (88,3\%). Secara keseluruhan pada proses transformasi penggunaan teknologi berperangkat keras lebih tinggi dari pada penggunaan teknologi berperangkat lunak.

Terdapat enam dari delapan teknologi berperangkat lunak yang penggunaannya cukup tinggi diatas 50\% atau dapat dikatakan bahwa $72,7 \%$ penggunaan teknologi berperangkat lunak cukup tinggi. Prosentase penggunaan teknologi berperangkat keras yang cukup tinggi sebesar 83,3\%. Dalam proses transformasi penggunaan teknologi berperangkat keras menjadi tumpuan dalam proses produksi sehingga UKM dapat memaksimalkan produksi, selain peranan penggunaan teknologi berperangkat lunak dalam peningkatan produktivitas.

Pada proses luaran, penggunaan teknologi dapat di bedakan menjadi dua bagian yaitu penggunaan teknologi berperangkat keras seperti Computer Aided Quality Control sebagai pengendalian kualitas produk dan teknologi berperangkat lunak seperti Accounting System and Activity Based Costing sebagai pengendalian sistem keuangan. Gambar 3 menunjukkan prosentase penggunaan AMT pada proses luaran dimana prosentase penggunaan teknologi berperangkat keras dan lunak diatas 50\%. Perbandingan penggunaan 
teknologi berperangkat keras dan lunak pada proses luaran adalah seimbang.

Pada area penggunaan AMT pada pengendalian lingkungan dapat diklasifikasikan sebagai berikut: Heating, Ventilation, and Air Conditioning System (HVAC) sebagai teknologi berperangkat keras dan Occupational Safety and Health Administration System (OSHAS) sebagai teknologi berperangkat lunak. Gambar 4 menunjukkan bahwa perbandingan penggunaan teknologi berperangkat keras dan lunak adalah sama. Prosentase penggunaan teknologi berperangkat keras dan lunak di atas ratarata $50 \%$.

Secara keseluruhan perbandingan prosentase penggunaan teknologi berperangkat keras dan lunak dapat dilihat pada Tabel 2.

Penggunaan teknologi berperangkat keras lebih tinggi dibandingkan dengan penggunaan teknologi berperangkat lunak. Hal ini membuktikan bahwa penggunaan AMT berperangkat keras lebih dominan dari tekonologi berperangkat lunak hal ini dikarenakan Indonesia masih berorientasi pada pengembangan teknologi berperangkat keras. Dalam upaya untuk meningkatkan produktivitas, UKM masih berorientasi pada peningkatan penggunaan teknologi berperangkat keras yang sifatnya tangible/ fisik. Sementara itu penggunaan teknologi yang berperangkat lunak belum banyak digunakan.

\section{Hubungan antara tingkat Penggunaan AMT dengan Tingkat Hasil Penjualan, Tingkat Keuntungan dan Kinerja Organisasi.}

Ada anggapan bahwa perusahaan besar lebih mudah untuk menerapkan AMT, hal ini dikarenakan faktor-faktor yang mempengaruhi penerapan AMT seperti investasi yang besar, ketersediaan sumber daya yang terampil sangat mudah terpenuhi. Lain halnya dengan UKM yang berbeda karakteristik serta berbeda klasifikasinya berdasarkan tingkat penjualan apakah mempengaruhi tingkat penggunaan AMT. Tabel 3. menunjukkan hasil pengelompokan ukuran UKM dengan penggunaan AMT. UKM mikro yang tingkat penjualannya kurang dari 100 juta terlihat tidak banyak menggunakan AMT dibandingkan dengan yang menggunakan AMT, tetapi sebaliknya UKM kategori menengah dan besar penggunaan AMT lebih tinggi dari pada yang tidak menggunakan.

Melalui anggapan yang telah ada dan berdasarkan hasil survey, akan diuji apakah anggapan bahwa perusahaan besar lebih mudah menerapkan AMT dari pada perusahaan mikro atau kecil.
Tabel 2. Ringkasan prosentase penggunaan AMT pada proses produksi

\begin{tabular}{lc}
\hline \multicolumn{1}{c}{ Proses } & \% Penggunaan AMT \\
\hline Input & 83,3 \\
- Teknologi lunak & 75,0 \\
- Teknologi keras & 100,0 \\
\hline Transformasi & 76,5 \\
- Teknologi lunak & 72,7 \\
- Teknologi keras & 83.3 \\
\hline Output & 100,0 \\
- Teknologi lunak & 100,0 \\
- Teknologi keras & 100,0 \\
\hline Lingkungan & 100,0 \\
- Teknologi lunak & 100,0 \\
- Teknologi keras & 100,0 \\
\hline Keseluruhan & 77,3 \\
- Teknologi lunak & 91,6 \\
\hline
\end{tabular}

Tabel 3. Pengelompokan ukuran UKM dengan tingkat penggunaan AMT

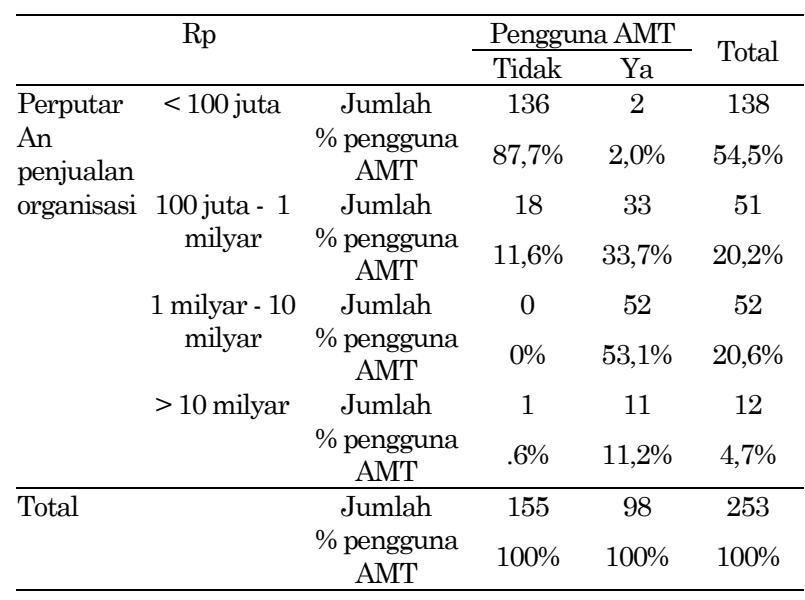

Tabel 4. Pengujian Chi-Square antara tingkat penjualan UKM dengan penggunaan AMT

\begin{tabular}{lccc}
\hline & Nilai & $d f$ & $\begin{array}{c}\text { Asymp. Sig. } \\
(2-s i d e d)\end{array}$ \\
\hline $\begin{array}{l}\text { Pearson Chi- } \\
\begin{array}{l}\text { Square } \\
\text { N of Valid Cases }\end{array}\end{array}$ & $1,918 \mathrm{E} 2$ & 3 &, 000 \\
\hline
\end{tabular}

Tabel 5. Pengelompokan tingkat keuntungan UKM dengan penggunaan AMT

\begin{tabular}{lrrrr}
\hline & \multicolumn{2}{c}{ Pengguna AMT } & \multirow{2}{*}{ Total } \\
\cline { 3 - 4 } & \multicolumn{2}{c}{ Tidak } & \multicolumn{1}{c}{ Ya } & \multicolumn{1}{c}{5} \\
\hline Keuntung Menurun & 5 & 0 & $5,0 \%$ \\
an & $3,2 \%$ &, $0 \%$ & $2,0 \%$ \\
organisasi Tetap & 76 & 15 & 91 \\
& & $49,0 \%$ & $15,3 \%$ & $36,0 \%$ \\
& Sedikit & 73 & 33 & 106 \\
& meningkat & $47,1 \%$ & $33,7 \%$ & $41,9 \%$ \\
& Sangat & 1 & 50 & 51 \\
& meningkat &, $6 \%$ & $51,0 \%$ & $20,2 \%$ \\
\hline Total & & 155 & 98 & 253 \\
& & $100 \%$ & $100 \%$ & $100 \%$ \\
\hline
\end{tabular}


Tabel 6. Pengujian Chi-Square antara tingkat keuntungan UKM dengan penggunaan AMT.

\begin{tabular}{lccc}
\hline & Value & Df & $\begin{array}{c}\text { Asymp. Sig. } \\
\text { (2-sided) }\end{array}$ \\
\hline $\begin{array}{l}\text { Pearson Chi-Square } \\
\text { N of Valid Cases }\end{array}$ & $\begin{array}{c}1,003 \mathrm{E} 2^{\text {a }} \\
269\end{array}$ & 3 &, 000 \\
\hline
\end{tabular}

Table 7. Hubungan antara penggunaan AMT dengan kinerja organisasi

\begin{tabular}{lcc}
\hline \multirow{2}{*}{ Performa Organisasi } & \multicolumn{2}{c}{ Menggunakan AMT } \\
\cline { 2 - 3 } & Tidak & Ya \\
\hline Clear mission & 69,7 & 91,9 \\
Develop good product and services & 57,5 & 93,9 \\
Ability to retain employees & 31,6 & 76,6 \\
Make realistic commitment to & 51,6 & 93,9 \\
customer & & \\
Teamwork & 32,3 & 62,2 \\
Treat employees with respect \& & 39,4 & 90,8 \\
dignity & & \\
Growth sales increase effectively & 28,7 & 78,5 \\
Profitability increase effectively & 16,8 & 80,6 \\
Proud to tell friends \& people with & 37,7 & 71,5 \\
the good one & & \\
Good communication & 34,4 & 84,7 \\
Financial performance highly & 30,3 & 84,7 \\
satisfactory compare to the other & & \\
company & & \\
\hline
\end{tabular}

Tabel 8. Pengujian Wilcoxon Signed Rank Test

\begin{tabular}{lc}
\hline & $\begin{array}{c}\text { Menggunakan - } \\
\text { tidak menggunakan } \\
\end{array}$ \\
\hline $\mathrm{Z}$ & AMT \\
\hline Asymp. Sig. (2-tailed) & $-2,934^{\mathrm{a}}$ \\
\hline
\end{tabular}

Tabel 4. menunjukan hasil dari pengujian ketergantungan antara ukuran UKM dengan tingkat penggunaan AMT. Kesimpulan yang didapat adalah terdapat ketergatungan yang signifikan antara ukuran UKM dan tingkat penggunaan AMT dengan nilai signifikansi 5\%. Benar adanya anggapan yang saat ini bahwa semakin besar ukuran UKM semakin tinggi penggunaan AMT. Dapat dikatakan bahwa penerapan AMT membawa dampak terhadap peningkatan penjualan perusahaan.

Begitu juga akan diuji apakah penggunaan AMT membawa dampak terhadap peningkatan keuntungan UKM. Tabel 5. menunjukkan pengelompokkan antara tingkat keuntungan UKM dengan penggunaan AMT.

Dari Table 5 dapat di deskripsikan bahwa UKM yang menerapkan AMT ada kecenderungan terjadi peningkatan keuntungan yang cukup tajam. Hasil Pengujian ketergantungan antara tingkat keuntungan UKM dengan penggunaan AMT dapat dilihat pada Tabel 6 .

Hasil pengujian chi-square menunjukkan bahwa nilai signifikansi dari Pearson Chi Square sebesar
0\% di bawah tingkat kesalahan penelitian sebesar 5\%. Hal ini menunjukkan bahwa ada ketergantungan antara Penggunaan AMT dengan Tingkat keuntungan UKM. Penggunaan AMT memberi dampak pada peningkatan keuntungan UKM.

Tabel 7. Memberikan uraian perbandingan kinerja organisasi yang menggunakan AMT dan yang tidak menggunakan AMT. UKM yang menggunakan AMT terlihat mempunyai kinerja yang lebih tinggi dari pada UKM yang tidak menggunakan AMT.

Hal ini dibuktikan juga dengan pengujian Wilcoxon Sign test pada Table 8 yang menyatakan bahwa terdapat perbedaan kinerja organisasi antara UKM yang menggunakan AMT dengan UKM yang tidak menggunakan AMT dengan nilai signifkansi 0.003. Indikasi ini menunjukkan bahwa Penggunaan AMT membawa dampak peningkatan kinerja organisasi yang pada akhirnya dapat mencapai tujuan dari organisasi yang telah dinyatakan dalam misi dan visi UKM. Peningkatan kinerja UKM membawa dampak peningkatan keuntungan melalui peningkatan kualitas produk atau kualitas jasa.

\section{Simpulan}

Penelitian ini menyimpulkan bahwa penerapan penggunaan AMT pada UKM di Indonesia sebesar $76,6 \%$ dan sisanya tidak menggunakan AMT. Kendala keuangan merupakan kendala yang paling besar (96,1\%) dihadapi oleh UKM di Indonesia. Hal ini sangat berhubungan dengan tipe kepemilikan perusahaan $62,1 \%$ adalah jenis kepemilikan keluarga dan perseorangan sehingga UKM ini mengalami keterbatasan modal dalam menginvestasikan AMT. Jika perusahaan melihat dengan teliti bahwa manfaat atau dampak AMT terhadap kinerja perusahaan seperti pertumbuhan omset penjualan tahunan, peningkatan profitabilitas dan kinerja organisasi yang tinggi, perusahaan akan diberikan kesempatan yagn luas untuk membuka pasar baru dan akan berdampak pada peningkatan partumbuhan ekonomi nasional.

Berdasarkan hasil survey dan penelitian sebelumnya maka AMT dapat diklasifikasikan menjadi dua kelompok yaitu teknologi berperangkat lunak dan teknologi berperangkat keras. Implementasi AMT dalam teknologi berperangkat keras banyak digunakan dalam proses input, transformasi dan proses output, serta lingkungan. Teknologi berperangkat lunak banyak digunakan dalam proses transformasi. Ini berarti bahwa untuk optimalisasi proses produksi akan lebih menekankan pada penggunaan teknologi berperangkat lunak. Untuk mengontrol kualitas produk lebih menekankan pada teknologi berperangkat keras. Kedua teknologi teknologi berprangkat keras dan teknologi berperangkat lunak adalah saling mendukung atau saling melengkapi 
satu sama lain. Dasar dari proses produksi dimulai dengan penggunaan teknologi berperangkat keras, diikuti dengan penggunaan teknologi berperangkat lunak sebagai optimasi dalam sistem produksi.

Analisis hubungan antara penggunaan AMT dengan omset penjualan, profitabilitas dan kinerja Organisasi diperoleh hasil bahwa hubungan yang signifikan antara Aplikasi AMT dan omset penjualan tahunan, tingkat profitabilitas, kinerja Organisasi. Perusahaan dengan omset penjualan yang tinggi dan profitabilitas tinggi lebih diterapkan AMT dari copmanies dengan rendah omset penjualan dan profitabilitas yang rendah. Dengan demikian perusahaan kecil dengan profitabilitas rendah dan omset penjualan rendah lebih sulit untuk menerapkan AMT. Terdapat beberapa usaha mikro atau kecil cenderung tidak menggunakan AMT karena kesulitan keuangan dan juga karena AMT tidak sesuai dengan perusahaannya. Usaha Mikro dan Kecil yang masih menggunakan proses produksi secara manual karena permintaan pasar yang rendah dan persyaratan kualitas yang rendah.

\section{Daftar Pustaka}

1. Raymond, L., and Croteau, A. M., Enabling the Strategic Development of SMEs through Advanced Manufacturing Systems: A Configurational perspective, Journal of Industrial Management \& Data Systems, 106(7), 2006, pp. 1012 1032.

2. Monge, C. A. M., Rao, S. S., Gonzales, M. E., and Sohal, A. S., Performance Measurement of AMT: A Cross-Regional Study, Benchmarking an International Journal, 13(1/2), 2006, pp. 135-146.

3. Saleh, A. S., and Ndubisi, N. O., An Evaluation of SME Development in Malaysia, International Review of Business Research Paper, 2(1), 2006, pp. 1-14.

4. Tambunan, T., SME Development, Economic Growth, and Government Intervention in a Developing Country: The Indonesian Story, Journal International Entrepreneur, 6, 2008, pp. 147-167.

5. Raymond L., Operations Management and Advanced Manufacturing Technologies in SMEs: A Contingency Approach, Journal of Manufacturing Technology Management, 16(8), 2005, pp. 936-955.

6. Deruntz, B. D., and Turner, R. M., Organizational Considerations for Advanced Manufacturing Technology, Journal of Technology Studies, 3, 2001, pp. 4-17.
7. Jonsson, P., An Empirical Taxonomy of Advanced Manufacturing Technology, International Journal of Operations \& Production Management, 20(12),2000, pp. 1446-1474.

8. Narain, R., Yadav, R. C., and Jiju A., Productivity Gains from Flexible Manufacturing Experiences from India, International Journal of Productivity and Performance Management, 53(2), 2004, pp. 109-128.

9. Salaheldin, I. S., The Impact of Organizational Characteristics on AMT Adoption: A Study of Egyptian Manufacturers, Journal of Manufacturing Technology Management,18(4), 2007, pp. 443-460.

10. Beaumont, N., Schroder, R. and Sohal, A. Do Foreign-Owned Firms Manage Advanced Manufacturing Technology Better, International Journal of Operations and Production Management, 22(7), 2002, pp 759-771.

11. Sun, H., Human Resources Development and Integrated Manufacturing Systems, Integrated Manufacturing Systems, Omega, 12(3), 2001, pp 195-204.

12. Sun, X. L., Tian, Y. Z., and Cui, G. G., The Empirical Study on the Impact of Advanced Manufacturing Technology on Organizational Structure and Human Resources Management, Proceeding International Conference on Management Science \& Engineering $\left(14^{\text {th }}\right)$, August 2022,2007, pp. 1548-53.

13. Small, M., Assessing Manufacturing Performance: An Advanced Manufacturing Technology Portfolio Perspective, Industrial Management \& Data Systems, 99(6), 1999, pp.266-78.

14. Vidyarthi N. K., and Lashkari, R. S., A MultiCriterion Decision Model for Advanced Manufacturing Technology Acquisition in Supply Chain Networks, Proceeding IEEE ICIT 2002, Bangkok, Thailand.

15. Small, M. H., and Yasin, M., Advanced Manufacturing Technology Adoption and Performance: The Role of Managament Information System Departments, Integrated Manufacturing System Journal, 14(5), 2003, pp.409-422.

16. Hashim, M. K, SMEs in Malaysia: A Brief Handbook, August Publication, Malaysia, 2007

17. Rahman, A. A.. Buyer-Supplier Relationships in Advanced Manufacturing Technology Acquisition and Implementation in Malaysia, International Journal of Economic and Management, 2(1), 2008, pp. 95-126. 